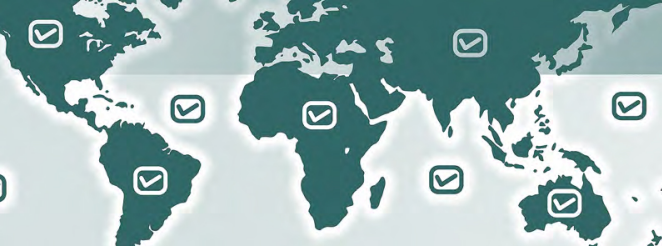

NOTES ON GEOGRAPHIC DISTRIBUTION

\title{
Anurans of the Agudos and Jaú municipalities, state of São Paulo, Southeastern Brazil
}

\author{
Fábio Maffei ${ }^{1 *}$, Bruno Tayar Marinho do Nascimento ${ }^{1}$, Guilherme Marson Moya ${ }^{2}$ and Reginaldo José Donatelli \\ 1 Universidade Estadual Paulista "Júlio de Mesquita Filho", Faculdade de Ciências, Departamento de Ciências Biológicas, Avenida \\ Engenheiro Luiz Edmundo Carrijo Coube, 14-01, CEP 17033-360, Bauru, SP, Brazil \\ 2 Instituto Pró-Terra, Rua Nicolau Piragine, 253, Chacará Bela Vista, CEP 17209070 Jaú, SP, Brazil \\ * Corresponding author. E-mail: maffei.fabio@gmail.com
}

\begin{abstract}
We present a list of amphibian species from the Agudos and Jaú municipalities, a Midwest region of São Paulo state, Brazil. The 26 species recorded exhibited a strong seasonality, with their reproductive periods concentrated in the rainiest months (October and December). Most of the species (88\%) are generalists and typically associated with open areas. Although none of the species to be associated exclusively forest environments, the occurrence of some species (12\%) depends on the proximity of water bodies for environments with forest formation. Thus, the presence of riparian forest fragments near water bodies is essential for some populations, as these sites are refuge for some species.
\end{abstract}

Key words: amphibians, Atlantic Forest, Cerrado, inventory, seasonality

\section{INTRODUCTION}

The Neotropical region has the largest diversity of amphibians in the world, and Brazil has the largest species richness with records of 1026 species (Segalla et al. 2014). The high levels of humidity and rainfall, in addition to the large habitat diversity, were conducive to the evolution of reproductive modes, which consequently contributed to the diversification of amphibians throughout the Neotropics (Duellman and Trueb 1994; Haddad and Prado 2005). The Cerrado (Brazilian savanna) and the Atlantic Forest have rich amphibian fauna with high rates of endemism. Currently, there are 209 known species of amphibians in the Cerrado biome, including 51.7\% endemism (Valdujo et al. 2012), in addition to 543 species in the Atlantic Forest, 88\% of which are endemic (Haddad et al. 2013). The Cerrado and Atlantic Forest currently exhibit only $34 \%$ and $14.5 \%$ of their original vegetation respectively (Machado et al. 2004; SOSMA and INPE 2013), and are considered biodiversity hotspots because of the rich biodiversity of these biomes, the large concentration of endemic species and the high threat level (Mittermeier et al. 2004).

The anuran fauna of the São Paulo state is the best studied of the country and includes records of 230 species (Rossa-Feres et al. 2011). The Atlantic Forest areas have an anuran fauna that is extremely rich and diverse with over 200 species compared with the more inland localities in the state, which have approximately 70 species (Araújo et al. 2009; Garcia et al. 2009). The Midwest region of the state has been studied since the 1970s, although the studies have been concentrated in the municipality of Botucatu (Jim and Caramaschi 1979; Rossa-Feres and Jim 1994; Jim 2003; SpirandelliCruz 2003; Melo et al. 2007). In the last decade, several studies have been conducted in the conservation areas of the Midwest region, including the following: Itirapina Ecological Station (Brasileiro et al. 2005), Assis Ecological Station (Ribeiro Jr. and Bertoluci 2009; Araujo and Almeida-Santos 2011), Caetetus Ecological Station (Brassaloti et al. 2010) and the Santa Bárbara Ecological Station (Araujo et al. 2013a). Other locations were recently surveyed, including Borebi (Maffei et al. 2011a), Lençóis Paulista (Maffei et al. 2011b), São Carlos (Sabbag and Zina 2011), and Araujo et al. (2013b) compiled the data from the middle Paranapanema basin. Despite the high level of knowledge of the anuran fauna of São Paulo, some regions have still not been sampled (RossaFeres et al. 2011). In this context, we present data here from two locations in the inland regions of São Paulo that have not been previously surveyed.

\section{MATERIALS AND METHODS \\ Study site}

The data were collected at two sampling points located in the municipalities of Agudos and Jaú, in the Midwest region of the state of São Paulo, in southeastern Brazil 


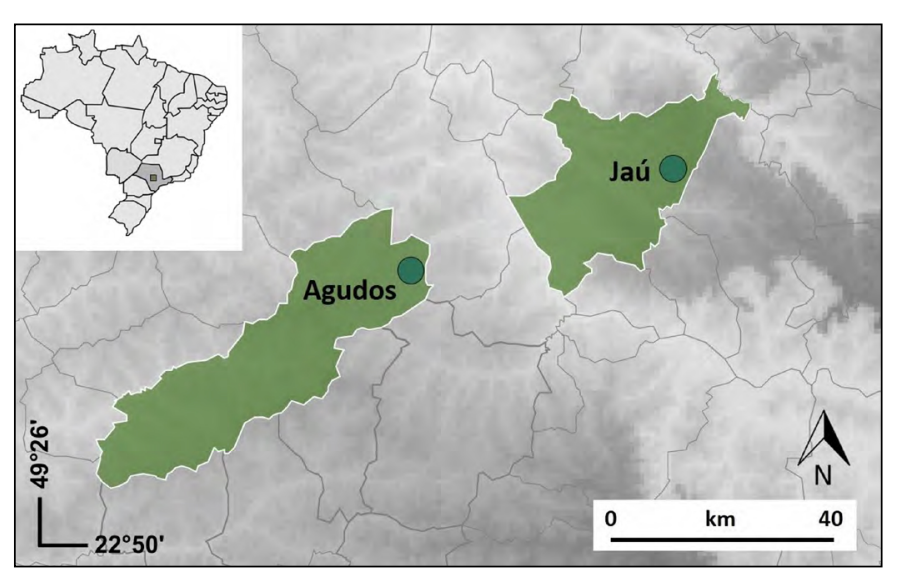

Figure 1. Map showing the sampled points in the state of São Paulo, Southeastern Brazil.

(Figure 1). The distance between areas was $46 \mathrm{~km}$. The areas were originally part of the Cerrado biome, but the proximity to the Atlantic Forest formations regarding the seasonal semideciduous forest subtype of these municipalities makes the area an ecotone (SOSMA and INPE 2013). In this transition zone, there is a mixture of floristic elements, geological formations and climate transition zones (IBGE 2004). According to the Köppen classification, the climate is Cwa (humid subtropical climate), which covers the entire central part of the State of São Paulo (Peel et al. 2007) and is characterized by summer rains (October to March) and dry winters (April to September). The mean annual rainfall is $1.600 \mathrm{~mm}$, $75 \%$ of which is concentrated in the summer months. The wettest month is January with approximately 20 days of rainfall and averaging $300 \mathrm{~mm} / \mathrm{month}$, and the month of August rarely experiences rainfall. The mean annual temperature is $20^{\circ} \mathrm{C}$, with a maximum temperature of $38^{\circ} \mathrm{C}$ in October and a minimum of $0^{\circ} \mathrm{C}$ in August, and frost may occur during the winter. Similar to the entire inland region of the state of São Paulo, the landscape of the Midwest region was significantly altered due to use of the land for various types of monocultures. The sampled areas are part of this mosaic and are isolated in small fragments of riparian forests surrounded by monocultures, mainly sugarcane and eucalyptus.

The sampling point in Agudos is a permanent largesized dam $(55 \times 130 \mathrm{~m})$ located on the Monte Alegre Farm $\left(22^{\circ} 25^{\prime} \mathrm{S}, 048^{\circ} 51^{\prime} \mathrm{W}\right.$, altitude $\left.548 \mathrm{~m}\right)$. The edge of the water body displays emergent vegetation, cattails (Typha sp.) and water lettuce (Pistia sp.). Downstream, the forest is flooded, and the riparian forest includes abandoned Pinus spp. plantations along one of the edges. The water flow is imperceptible, and variations in the water level during the year are minimal. The maximum depth is approximately $4 \mathrm{~m}$. At the peak of the rains, temporary ponds are formed around the areas at the edges of roads and within the eucalyptus plantations. The surrounding area consists of eucalyptus plantations and "cerradão" (dense woodland) types of forested areas. In Jaú, the sampling was performed at a small-sized dam $(25 \times 30 \mathrm{~m})$ on the Santo Antônio Farm $\left(22^{\circ} 16^{\prime} \mathrm{S}, 048^{\circ} 26^{\prime} \mathrm{W}\right.$, altitude 688). The point was formed by a dam on a small stream with grassy vegetation along the edges and cattails at the transition between the weir and the riparian forest. The source of this water body is 150 meters away and was also sampled. The maximum depth is $1.5 \mathrm{~m}$ and the water level does not change throughout the year. In periods of heavy rainfall, a small water runoff channel is formed at the side of the dam. The surrounding area consists of sugar cane plantations and pasture.

\section{Data collection}

Regular field visits were conducted between May 2012 and April 2013. The campaigns were performed biweekly during the rainy season (October to March) and monthly throughout the remaining sampling period. After this period, additional visits were conducted in January and February 2014. To record the species, two complementary methods were used simultaneously: surveys at reproductive sites (Scott Jr. and Woodward 1994) and audio strip transects (Zimmerman 1994). The data collection was performed during the vocalization period, beginning at 18:00 $\mathrm{h}$ and ending at midnight. Each hour, the perimeters of the water bodies were covered, and the number of males engaging in vocalization activity was recorded. Specimens were collected as a voucher-specimen (License SISBIO 40639-1). The individuals were manually captured and later anesthetized and sacrificed with a 5\% lidocaine paste. The specimens were then fixed in $10 \%$ formalin for three days and preserved in $70 \%$ alcohol. The material was deposited in the Amphibian Collection of the Department of Zoology at São Paulo State University, São José do Rio Preto municipality, state of São Paulo, Brazil (Appendix 1). The nomenclature adopted for this study followed Frost (2014).

\section{RESULTS}

Within the two locations, a total of 26 species were recorded belonging to the following four families: Bufonidae (2), Hylidae (11), Leptodactylidae (11) and Microhylidae (2) (Table 1; Figures 2 and 3). The species richness was similar in two areas, 22 and 20 species in Jaú and Agudos, respectively. Ten species were exclusive to a single location ( 5 in Agudos and 5 in Jaú). The species Dendropsophus minutus, Hypsiboas faber, Phyllomedusa tetraploidea, Scinax fuscovarius, Physalaemus nattereri, Leptodactylus fuscus, L. mystaceus, L. mystacinus, Physalaemus cuvieri, P. marmoratus and Chiasmocleis albopunctata were recorded in temporary ponds near the weirs that were sampled. The period of activity for these species was seasonal and concentrated in the rainy season. The Jaú sampling point had specimens recorded in all months, while in Agudos, there were no species 
recorded in the months of May, June or July (Figure 4). Four species were only recorded visually (Leptodactylus latrans, Rhinella schneideri, Scinax similis and Trachycephalus typhonius).

\section{DISCUSSION}

The species recorded in the present study are typical of the Cerrado and Atlantic Forest biomes, and most of the species were widely distributed. Dendropsophus minutus, D. nanus and Physalaemus cuvieri are most likely the most common species in Brazil and occur in all the biomes (Frost 2014). Other species also occur in various regions, such as Rhinella schneideri, Hypsiboas albopunctatus, Scinax fuscomarginatus, S. fuscovarius, Trachycephalus typhonius, Leptodactylus fuscus, L. labyrinthicus, L. latrans, L. mystaceus, L. mystacinus, $L$.
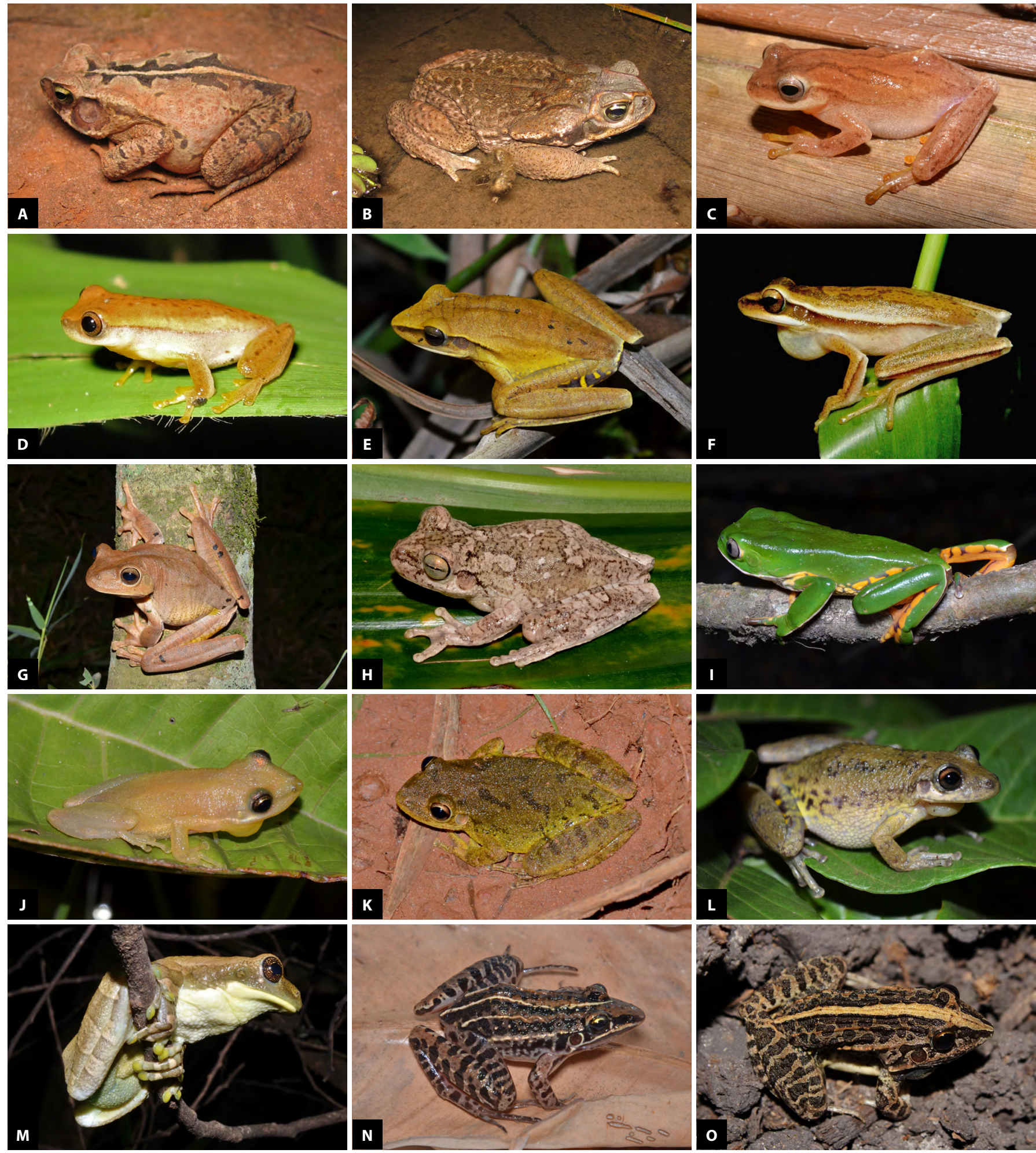

Figure 2. Species of amphibians recorded in the Agudos and Jaú municipalities, state of São Paulo, Southeastern Brazil. A, Rhinella ornata; B, Rhinella schneideri; C, Dendropsophus minutus; D, Dendropsophus nanus; E, Hypsiboas albopunctatus; F, Hypsiboas caingua; G, Hypsiboas faber; H, Hypsiboas lundii; I, Phyllomedusa tetraploidea; J, Scinax fuscomarginatus; $\mathbf{K}$, Scinax fuscovarius; L, Scinax similis; $\mathbf{M}$, Trachycephalus typhonius; $\mathbf{N}$, Leptodactylus furnarius; $\mathbf{0}$, Leptodactylus fuscus. 

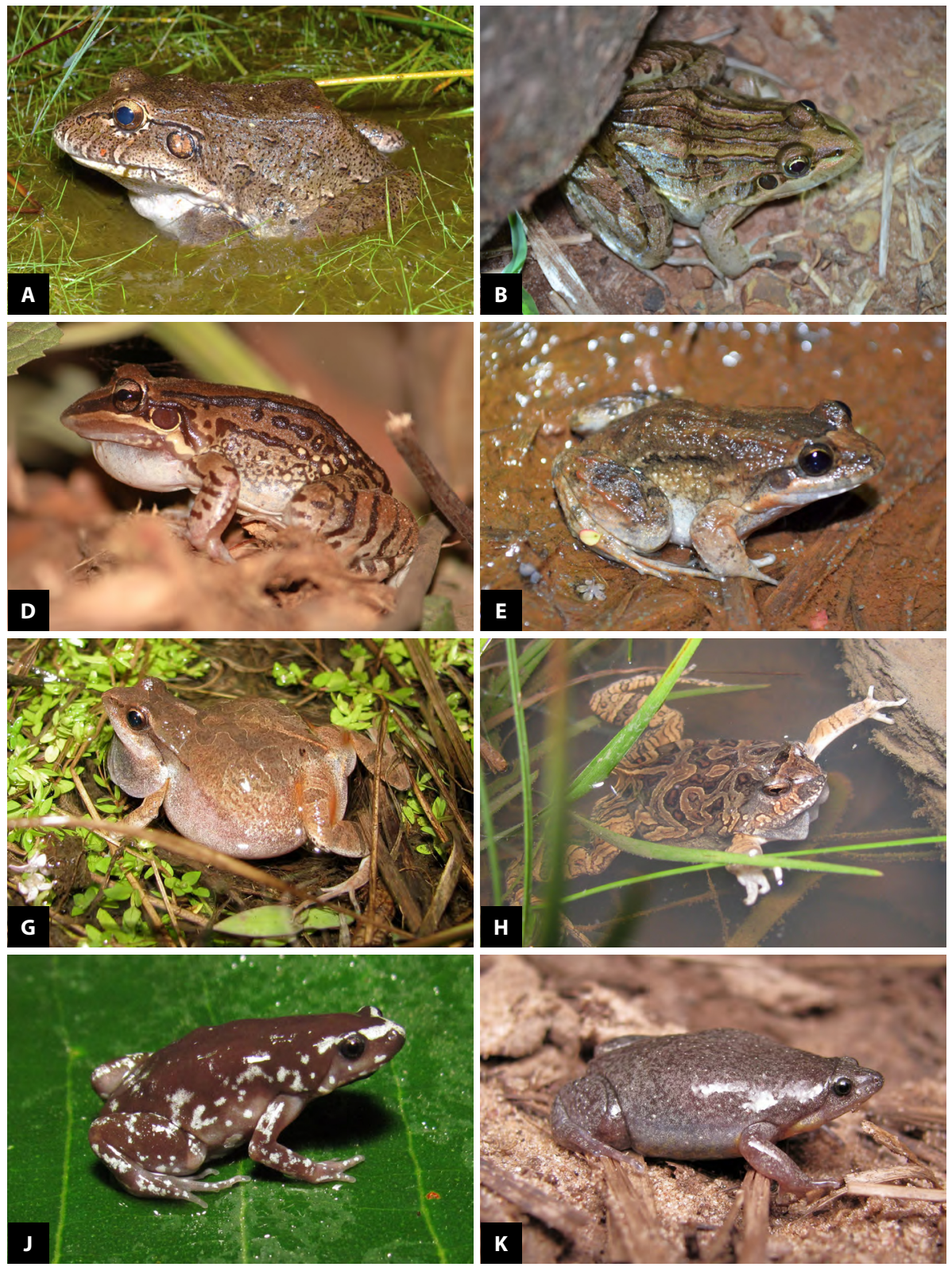
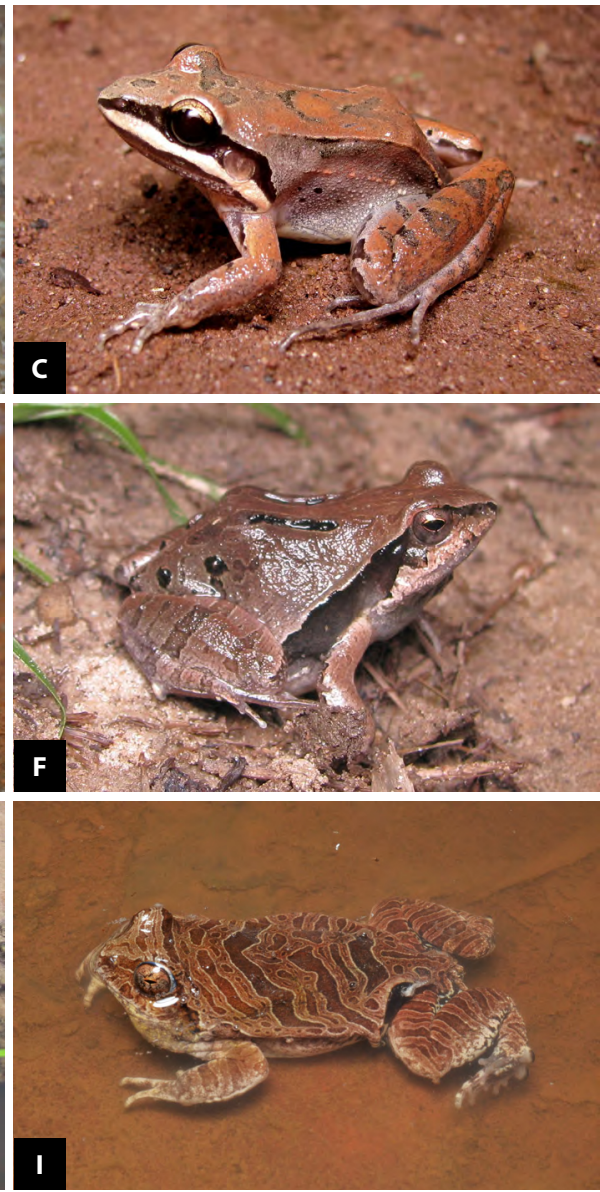

I

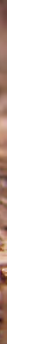

Figure 3. Species of amphibians recorded in the Agudos and Jaú municipalities, state of São Paulo, Southeastern Brazil. A, Leptodactylus labyrinthicus; B, Leptodactylus latrans; C, Leptodactylus mystaceus; $\mathbf{D}$, Leptodactylus mystacinus; $\mathbf{E}$, Leptodactylus podicipinus; $\mathbf{F}$, Physalaemus centralis; $\mathbf{G}$, Physalaemus cuvieri; $\mathbf{H}$, Physalaemus marmoratus; I, Physalaemus nattereri; J, Chiasmocleis albopunctata; $\mathbf{K}$, Elachistocleis cesarii.

Table 1. List of species of anurans sampled in the Agudos and Jaú municipalities, São Paulo state, Brazil (OA = Open area; BF = Border forest).

\begin{tabular}{lccc}
\hline Family/Species & Agudos & Jaú & Habitat \\
\hline Bufonidae & & & \\
Rhinella ornata (Spix, 1824) & $\mathrm{X}$ & & $\mathrm{BF}$ \\
Rhinella schneideri (Werner, 1894) & $\mathrm{X}$ & $\mathrm{X}$ & $\mathrm{OA}$ \\
\hline Hylidae & & & \\
Dendropsophus minutus (Peters, 1872) & $\mathrm{X}$ & $\mathrm{X}$ & $\mathrm{OA}$ \\
Dendropsophus nanus (Boulenger, 1889) & $\mathrm{X}$ & $\mathrm{X}$ & $\mathrm{OA}$ \\
Hypsiboas albopunctatus (Spix, 1824) & $\mathrm{X}$ & $\mathrm{X}$ & $\mathrm{OA}$ \\
Hypsiboas caingua (Carrizo, 1991) & $\mathrm{X}$ & $\mathrm{X}$ & $\mathrm{OA}$ \\
Hypsiboas faber (Wied-Neuwied, 1821) & $\mathrm{X}$ & $\mathrm{X}$ & $\mathrm{OA}$ \\
Hypsiboas lundii (Burmeister, 1856) & $\mathrm{X}$ & $\mathrm{X}$ & $\mathrm{BF}$ \\
Phyllomedusa tetraploidea Pombal \& Haddad, 1992 & $\mathrm{X}$ & & $\mathrm{OA}$ \\
Scinax fuscomarginatus (A. Lutz, 1925) & & $\mathrm{X}$ & $\mathrm{OA}$ \\
Scinax fuscovarius (A. Lutz, 1925) & $\mathrm{X}$ & $\mathrm{X}$ & $\mathrm{OA}$ \\
Scinax similis (Cochran, 1952) & & $\mathrm{X}$ & $\mathrm{OA}$ \\
Trachycephalus typhonius (Linnaeus, 1758) & & $\mathrm{X}$ & $\mathrm{OA}$
\end{tabular}

\begin{tabular}{|c|c|c|c|}
\hline Family/Species & Agudos & Jaú & Habitat \\
\hline \multicolumn{4}{|l|}{ Leptodactylidae } \\
\hline Physalaemus nattereri (Steindachner, 1863) & $\mathrm{x}$ & $\mathrm{x}$ & OA \\
\hline Leptodactylus furnarius Sazima \& Bokermann, 1978 & & $\mathrm{x}$ & OA \\
\hline Leptodactylus fuscus (Schneider, 1799) & $\mathrm{x}$ & $\mathrm{x}$ & $\mathrm{OA}$ \\
\hline Leptodactylus labyrinthicus (Spix, 1824) & $\mathrm{x}$ & $\mathrm{x}$ & OA \\
\hline Leptodactylus latrans (Steffen, 1815) & & $\mathrm{x}$ & $\mathrm{OA}$ \\
\hline Leptodactylus mystaceus (Spix, 1824) & $\mathrm{x}$ & $\mathrm{x}$ & $\mathrm{OA} / \mathrm{BF}$ \\
\hline Leptodactylus mystacinus (Burmeister, 1861) & $\mathrm{x}$ & $\mathrm{x}$ & $\mathrm{OA}$ \\
\hline Leptodactylus podicipinus (Cope, 1862) & $\mathrm{x}$ & $\mathrm{x}$ & OA \\
\hline Physalaemus centralis Bokermann, 1962 & $\mathrm{x}$ & & $\mathrm{OA}$ \\
\hline Physalaemus cuvieri Fitzinger, 1826 & $\mathrm{x}$ & $\mathrm{x}$ & OA \\
\hline $\begin{array}{l}\text { Physalaemus marmoratus (Reinhardt \& Lütken, } \\
\text { 1862) }\end{array}$ & $\mathrm{x}$ & $\mathrm{x}$ & $\mathrm{OA}$ \\
\hline \multicolumn{4}{|l|}{ Microhylidae } \\
\hline Chiasmocleis albopunctata (Boettger, 1885) & $\mathrm{x}$ & & $\mathrm{OA}$ \\
\hline Elachistocleis cesarii (Miranda-Ribeiro, 1920) & & $\mathrm{x}$ & $\mathrm{OA}$ \\
\hline Richness & 20 & 22 & \\
\hline
\end{tabular}




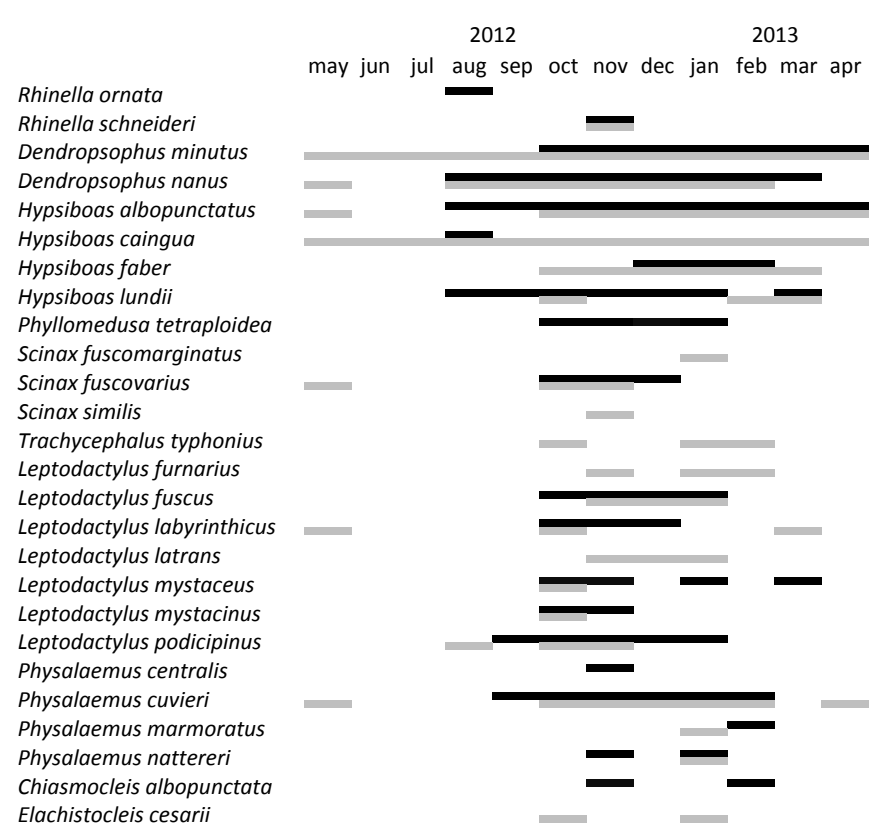

Figure 4. Months of occurrence of the anuran species between May 2012 and April 2013. Black bars represent the presence of the species in Agudos municipality and gray bars in Jaú municipality.

podicipinus and Elachistocleis cesarii (Valdujo et al. 2012; Haddad et al. 2013; Frost 2014). The following species are considered endemic to the Cerrado biome: Physalaemus nattereri, Physalaemus centralis, P. marmoratus, Leptodactylus furnarius and Chiasmocleis albopunctata (Valdujo et al. 2012). Hypsiboas lundii is also considered endemic to the Cerrado (Valdujo et al. 2012), although this species frequently occurs in areas of the Atlantic Forest in this region (Maffei et al. 2011b). Phyllomedusa tetraploidea and Hypsiboas caingua are species that are distributed toward the southern end of the continent, and the sampled regions constitute the northern limits for the occurrence of these species (Souza-Filho and Lima 2012; Fisch and Port 2013). Most species have records in nearby localities. All species recorded here were also recorded in Lençóis Paulista (35 km away from Agudos; Maffei et al. 2011a), except Trachycephalus typhonius. In Itirapina Ecological Station (6o km away from Jaú), Brasileiro et al. (2005) recorded 21 species of the species recorded in the present study.

The anuran fauna of this region is basically formed by species typical of open formations of dry diagonal (complex Cerrado-Caatinga-Chaco, sensu Duellman 1999). Twenty-four species had habitats in open areas, and 23 of these species were exclusive to these formations. None of the recorded species were exclusive to the interior of the forest, but three species used the edge of the forest as their vocalization site (Hypsiboas lundii, Rhinella ornata and Leptodactylus mystaceus). The points were open environments with full sunshine but were connected to a riparian forest. This proximity to areas with vegetation cover leads to the presence of species associated to forested areas, but this with different levels of dependency on forested habitats (Brandão and Araújo 2000; Jim 2003; Brasileiro et al. 2005). These species are dependent on the forest as they do not occur in distant bodies of water or isolated forested areas and even use areas with forested streams as reproductive sites (Brasileiro et al. 2005; Jim 2003). This connection of bodies of water with forested areas is also important for open-area species. Silva and RossaFeres (2007) found that forest fragments constitute an important part of the habitat for these species, either as refuge areas during the dry season, as daytime shelters during the reproductive season or as foraging areas. The separation between habitats and the isolation of fragments of reproductive areas influence the decrease in species richness of anurans, particularly for species with aquatic larvae (Becker et al. 2007).

Areas of seasonal semideciduous forest and Cerrado are marked by seasonality climate, with the highest abundance and greatest richness of anurans occurring during the hot and rainy months (Toledo et al. 2003; Vasconcelos and Rossa-Feres 2005; Santos et al. 2007). The pronounced dry season effectively concentrates the reproductive activity of these species in the height of the summer (Giaretta et al. 2008; Santos et al. 2009; Both et al. 2008). In addition to the reproductive activity being concentrated in the summer, the start of the rainy season, especially the month of November, is also the peak of anuran vocalization activity (Toledo et al. 2003; Kopp and Eterovick 2008). The increase in temperature and the high levels of rainfall during this month probably explain this effect. The highest abundances of Leptodactylidae species were recorded the beginning of the rainy season, and those of Hylidae were recorded throughout the entire rainy season. This behavior can be related to the reproductive modes of most of the species from both of these families. Hylids mostly have a type 1 reproductive mode, which is the most widespread among amphibians and the oviposition occurs directly in the water (Haddad and Prado 2005). While, species of Leptodactylidae, given that their reproductive modes include foam nests or burrows (Modes 11, 13 and 30, sensu Haddad and Prado 2005), take advantage of the first rains to reproduce (Brasileiro et al. 2005; Santos et al. 2007). These reproductive modes rely on increasing and maintaining the water level to prevent the desiccation of the eggs and/or carrying the eggs/tadpoles into the water bodies, since open areas tend to be less predictable and stable in relation to the conditions climate compared to forest environments (Kopp et al. 2010).

The two communities sampled have low species richness compared to the communities in rainforest areas. The inland areas of the state of São Paulo are historically less diverse than the areas close to the São Paulo coast. This discrepancy is a result of several interrelated factors, such as topography, altitude, 
rainfall, humidity and temperature (Rossa-Feres et al. 2011; Haddad et al. 2013). According to Silva et al. (2012), regions with strong seasonal climates support only those reproductive modes that are resistant to the desiccation of eggs, thus reducing the phylogenetic diversity of the given region. The low rainfall recorded for nearly nine months of the year in the inland areas of the state of São Paulo provides few survival opportunities for groups with complex reproductive modes, which is reflected in the lower diversity of this region.

\section{ACKNOWLEDGEMENTS}

We thank Flávio K. Ubaid for providing helpful comments on the manuscript and Hélio Maffei for field assistance. We also thank João Desejácomo for allowed the research on Santo Antônio Farm, and Duratex S.A. and FUNDIBIO for financial support. Denise C. RossaFeres allowed the deposit of specimens in the Amphibian Collection (DZSJRP). FM thanks CAPES for fellowship.

\section{LITERATURE CITED}

Araujo, C.O. and S.M. Almeida-Santos. 2011. Herpetofauna de um remanescente de Cerrado no estado de São Paulo, sudeste do Brasil. Biota Neotropica 11(3): 48-62. doi: 10.159o/S1676-06o320 11000300003

Araujo, C.O., D.T. Corrêa and S.M. Almeida-Santos. 2013a. Anuros da Estação Ecológica de Santa Bárbara, um remanescente de formações abertas de Cerrado no estado de São Paulo. Biota Neotropica 13(3): 2-11. doi: 10.1590/S1676-06032013000300026

Araujo, C.O., C.K. Matsukumaand S.M. Almeida-Santos. 2013b. Composição taxonômica e distribuição de anuros no Alto e Médio Paranapanema, estado de São Paulo. Biota Neotropica 13(3): 2-18. doi: 10.1590/S1676-06032013000300027

Araújo, O.G.S., L.F. Toledo., P.C.A. Garcia and C.F.B. Haddad. 2009. The amphibians of São Paulo State. Biota Neotropica 9(4): 197-209. doi: 10.1590/S1676-06032009000400020

Becker, C.G., C.R. Fonseca,. C.F.B. Haddad,. R.F. Batista and P.I Prado. 2007. Habitat split and the global decline of amphibians. Science 5857(318):1775-1777. doi: 10.1126/science.1149374

Both, C., I.L. Kaefer, T.G. Santos and S.T.Z. Cechin. 2008. An austral anuran assemblage in the Neotropics: seasonal occurrence correlated with photoperiod. Journal of Natural History 42(3-4): 205-222. doi: 10.1080/00222930701847923

Brandão, R.A. and A.F.B. Araújo. 200o. A herpetofauna associada a matas de galeria no Distrito Federal; pp. 560-604, in: J.F. Ribeiro., C.E.L. Fonseca and J.C. Sousa-Silva (Orgs.). Cerrado: caracterização e recuperação de matas de galeria. Planaltina: EMBRAPA/CPAC.

Brasileiro, C.A., R.J. Sawaya., M.C. Kiefer and , M. Martins. 2005. Amphibians of an open Cerrado fragment in southeastern Brazil. Biota Neotropica 5(2): 2-17. doi: 10.1590/S167606032005000300006

Brassaloti, R.A., D.C. Rossa-Feres and J. Bertoluci. 2010. Anurofauna da Floresta Estacional Semidecidual da Estação Ecológica dos Caetetus, sudeste do Brasil. Biota Neotropica 10(1): 276-291. doi: 10.1590/S1676-06032010000100024

Duellman, W.E. and L. Trueb. 1994. Biology of Amphibians. Baltimore, Johns Hopkins University Press. 670 pp.

Duellman, W.E. 1999. Distribution patterns of amphibians in South America; pp. 255-328, in: W.E. Duellman (ed.). Patterns of distribution of amphibians: a global perspective. Baltimore: John Hopkins University Press.
Fisch, F. and D. Port. 2013. Localidades de ocorrência de Phyllomedusa tetraploidea Pombal \& Haddad, 1992 (Anura: Hylidae: Phyllomedusinae) e novo registro para Santa Catarina, Brasil. Boletim do Museu de Biologia Mello Leitão (N. Sér.) 32: 13-28. http:// www.boletimmbml.net/boletim/index.php/boletim_mbml/ article/view/1/15

Forlani, M.C., P.H. Bernardo., C.F.B. Haddad and H. Zaher. 2010. Herpetofauna do Parque Estadual Carlos Botelho, São Paulo, Brasil. Biota Neotropica 10(3): 265-309. doi: 10.1590/S167606032010000300028

Frost, D.R. 2014. Amphibian species of the world: an online reference. Version 6.o. New York: American Museum of Natural History. Accessed athttp://research.amnh.org/herpetology/amphibia/ index.html, 8 August 2014.

Garcia, P.C.A., R.J. Sawaya., I.A. Martins., C.A. Brasileiro., V. Verdade., J. Jim, ., M.V. Segalla. , M. Martins. , D.C. Rossa-Feres. , C.F.B. Haddad. , L.F. Toledo. , C.P.A. Prado. , B.M. Berneck and O.G.S. Araújo. 2009. Anfíbios; pp. 329-347, in: P.M. Bressan., M.C.M. Kierulff and A.M. Sugieda (eds.). Fauna Ameaçada de Extinção do Estado de São Paulo: Vertebrados. São Paulo: Fundação Parque Zoológico de São Paulo.

Giaretta, A.A., M. Menin., K.G. Facure. , M.N.C. Kokubum and J.C. OliveiraFilho. 2008. Species richness, relative abundance, and habitat of reproduction of terrestrial frogs in the Triângulo Mineiro region, Cerrado biome, southeastern Brazil. Iheringia, Série Zoologia 98(2):181-188. doi: 10.1590/So073-47212008000200002

Haddad, C.F.B. and C.P.A. Prado. 2005. Reproductive modes in frogs and their unexpected diversity in the Atlantic Forest of Brazil. BioScience 55(3):207-217.

Haddad, C.F.B., L.F. Toledo., C.P.A. Prado., D. Loebmann., J.L. Gasparini. and I. Sazima. 2013. Guia dos Anfíbios da Mata Atlântica: Diversidade e Biologia. São Paulo: Anolis Books. 543p. Heyer, W.R., A.S. Rand., C.A.G. Cruz., O.L. Peixoto, and C.E. Nelson. 1990. Frogs of Boracéia. Arquivos de Zoologia 31:231-410.

IBGE. 2004. Instituto Brasileiro de Geografia e Estatística. Mapa de biomas do Brasil - Escala 1:5.000.00o. Database accessible atftp:// ftp.ibge.gov.br/Cartas_e_Mapas/Mapas_Murais/biomas_pdf. zip, 10 August 2013.

Jim, J. 2003. Aspectos gerais da anurofauna da região de Botucatu; pp. 75-89, in: W. Uieda and L.M. Paleari (Org.). Flora e fauna: um dossiê ambiental. São Paulo, Editora da UNESP.

Jim, J. and U. Caramaschi. 1979. Uma nova espécie de Hyla da região de Botucatu, São Paulo, Brasil (Amphibia, Anura). Revista Brasileira de Biologia 39(3): 717-719.

Kopp, K., L. Signorelli and R. P. Bastos. 2010. Distribuição temporal e diversidade de modos reprodutivos de anfíbios anuros no Parque Nacional das Emas e entorno, estado de Goiás, Brasil. Iheringia, Série Zoologia 100(3): 192-200.

Kopp, K. and P.C. Eterovick. 2006. Factors influencing spatial and temporal structure of frog assemblages at ponds in southeastern Brazil. Journal of Natural History 40:29-31 (doi: 10.1080/00222930601017403).

Machado, R.B., M.B. Ramos Neto., P.G.P. Pereira., E.F. Caldas., D.A. Gonçalves., N.S. Santos., K. Tabor and M. Steininger. 2004. Estimativas de perda da área do Cerrado brasileiro. Conservation International do Brasil, Brasília. 26 pp..

Maffei, F., F.K. Ubaid and J. Jim. 2011a. Anurofauna em área de cerrado aberto no município de Borebi, estado de São Paulo, Sudeste do Brasil: uso do habitat, abundância e variação sazonal. Biota Neotropica 11(2): 202-213.

Maffei, F., F. K. Ubaid. and J. Jim. 2011b. Anfíbios da Fazenda Rio Claro, Lençóis Paulista, SP, Brasil. Bauru: Editora Canal 6. 126 pp.

Melo, G.V., D.C. Rossa-Feres and J. Jim. 2007. Variação temporal no sítio de vocalização em uma comunidade de anuros de Botucatu, Estado de São Paulo, Brasil. Biota Neotropica 7(2): 93-102 .

Mittermeier, R.A., P.R. Gil., M. Hoffmann., J. Pilgrin., T. Brooks., 
C.G. Mittermeier., J. Lamoreux and G.A.B. Fonseca. 2004. Hotspots revisited. Earth's biologically richest and most endangered terrestrial ecoregions. Sierra Madre: Cemex Conservation International. $392 \mathrm{pp}$.

Peel, M.C., B.L. Finlayson and T.A. Mcmahon. 2007. Updated world map of the Köppen-Geiger climate classification. Hydrology and Earth System Sciences 11:1633-1644. doi: 10.5194/hess-11-16332007

Ribeiro Jr., J.W. and J. Bertoluci. 2009. Anuros do cerrado da Estação Ecológica e da Floresta Estadual de Assis, sudeste do Brasil. Biota Neotropica 9(1): 207-216. doi: 10.1590/S1676-0603 2009000100020

Rossa-Feres, D.C. and J. Jim. 1994. Distribuição sazonal em comunidades de anfíbios anuros na região de Botucatu, São Paulo. Revista Brasileira de Biologia 54(2): 323-334.

Rossa-Feres, D.C., R.J. Sawaya., J. Faivovich., J.G.R. Giovanelli., C.A. Brasileiro., L. Schiesari., J. Alexandrino and C.F.B. Haddad. 2011. Anfíbios do Estado de São Paulo, Brasil: conhecimento atual e perspectivas. Biota Neotropica 11(1): 1-19. doi: 10.1590/S167606032011000500004

Sabbag, A.F. and J. Zina. Anurans of a riparian forest in São Carlos, state of Sao Paulo, Brazil. Biota Neotropica 11(3):180-188. doi: 10.1590/S1676-06032011000300015

Santos, T.G., D.C. Rossa-Feres and L. Casatti. 2007. Diversidade e distribuição espaço-temporal de anuros em região com pronunciada estação seca no sudeste do Brasil. Iheringia, Série Zoologia 97(1): 37-49. doi: 10.159o/Soo73-47212007000100007

Santos, T.G., T.S. Vasconcelos., D.C. Rossa-Feres and C.F.B. Haddad. 2009. Anurans of a seasonally dry tropical Forest: Morro do Diabo State Park, São Paulo state, Brazil. Journal of Natural History 43(15-16): 973-993. doi: 10.1080/00222930802702498

Scott Jr., N.J. and B. D. Woodward. 1994. Standard techniques for inventory and monitoring: Surveys at Breeding Sites; pp.118-125, in: W.R. Heyer., M.A. Donnelly., R.W. McDiarmid., L.C. Hayek and M.S. Foster (Eds). Measuring and Monotoring Biological Diversity. Standard Methods for Amphibians. Washington, D.C., Smithsonian Institution Press, 364p.

Segalla, M.V., U. Caramaschi., C.A.G. Cruz., T. Grant., C.F.B. Haddad., J. Langone and P.C.A. Garcia. 2014. Brazilian amphibians - list of species. Herpetologia Brasileira 3(2): 37-48.

Silva, F.R. and D.C. Rossa-Feres. 2007. Uso de fragmentos florestais por anuros (Amphibia) de área aberta na região noroeste do Estado de São Paulo. Biota Neotropica 7(2): 141-148. doi: 10.159o/ S1676-06032007000200016

Silva, F.R., M. Almeida-Neto., V.H.M. Prado., C.F.B.Haddad and D.C. Rossa-Feres. 2012. Humidity levels drive reproductive modes and phylogenetic diversity of amphibians in the Brazilian Atlantic Forest. Journal of Biogeography 39(9):1720-1732. doi: 10.1111/j.1365-2699.2012.02726.x

SOSMA (Fundação SOS Mata Atlântica) and INPE (Instituto Nacional de Pesquisas Espaciais). 2013. Atlas dos remanescentes florestais da Mata Atlântica: período 2010-2011. São Paulo. 120 pp.

Souza Filho, G.A. and A.M.X. Lima. 2012. Hypsiboas caingua (Carrizo, 1990) (Amphibia: Anura: Hylidae): geographic distribution with a new state record in Brazil. Check List 8(4): 80o-801. http:// www.checklist.org.br/getpdf?NGDoo4-12

Spirandeli-Cruz, E.F. 2003. Anfíbios anuros de remanescentes de mata atlântica na região de Botucatu; pp. 91-98, in: W., Uieda and L.M. Paleari. (Org.). Flora e fauna: um dossiê ambiental. São Paulo, Editora da UNESP.

Toledo, L.F., J. Zina and C.F.B. Haddad.2003. Distribuição espacial e temporal de uma comunidade de anfíbios anuros do município de Rio Claro, São Paulo, Brasil. Holos Environment 3(2):136-149.

Valdujo, P.H., D.L. Silvano., G. Colli and M. Martins. 2012. Anuran species composition and distribution patterns in Brazilian Cerrado, a Neotropical Hotspot. South American Journal of Herpetology 7(2): 63-78. doi: 10.2994/057.007.0209

Vasconcelos, T.S. and D.C. Rossa-Feres. 2005. Diversidade, distribuição espacial e temporal de anfíbios anuros (Amphibia, Anura) na região Noroeste do Estado de São Paulo, Brasil. Biota Neotropica 5(2):1-14. doi: 10.1590/S1676-06032005000300010

Zimmerman, B.L. 1994. Audio Strip Transects; pp. 92-97, in: W.R. Heyer., M.A. Donnelly., R.W. McDiarmid., L.A.C. Hayek and M.S. Foster. (Eds.). Measuring and Monitoring Biological Diversity: Standard Methods for Amphibians. Washington, Smithsonian Institution Press.

Authors' contribution statement: FM, BTMN, GMM collected the data, FM and RJD wrote the text.

Received: August 2014

Accepted: March 2015

Editorial responsibility: Raul Maneyro

Appendix 1. Voucher list.

Agudos: Chiasmocleis albopunctata (14484); Dendropsophus minutus (14486); Dendropsophus nanus (14487); Physalaemus nattereri (14471); Hypsiboas albopunctatus (14480); Hypsiboas caingua (14483); Hypsiboas faber (14491); Leptodactylus fuscus (14479); Leptodactylus mystaceus (14478); Leptodactylus mystacinus (14477); Leptodactylus podicipinus (14482); Phyllomedusa tetraploidea (14476); Physalaemus cuvieri (14507); Physalaemus marmoratus (14485); Rhinella ornata (14488); Scinax fuscovarius (14481).

JAÚ: Dendropsophus minutus (14469); Dendropsophus nanus (14465); Elachistocleis cesarii (14468); Physalaemus nattereri (14473); Hypsiboas albopunctatus (14464); Hypsiboas caingua (14466); Hypsiboas faber (14457); Hypsiboas lundii (14458); Leptodactylus furnarius (14462); Leptodactylus fuscus (14460); Leptodactylus labyrinthicus (14461); Leptodactylus latrans (14455); Leptodactylus mystaceus (14470); Leptodactylus mystacinus (14459); Physalaemus cuvieri (14472); Physalaemus marmoratus (14467); Rhinella schneideri (14474); Scinax fuscovarius (14463); Scinax similis (14475); Trachycephalus typhonius (14456). 